\title{
The politics of Cultural Revalidation and Retrieval: A peep into the Yoruba paradigm in Wole Soyinka's A Dance of the Forests.
}

\author{
Pinky Isha \\ (Department of English, Milli Al-Ameen College,University of Calcutta, India.)
}

\begin{abstract}
This research paper attempts to study and discover the patterns of myth and religious interfaces in Wole Soyinka's drama A Dance of the Forests. Soyinka has traditionally been allied to an elitist and western European canon of writing. But in A Dance we see how the European traditions of word drama and the African tradition of performance combine to form a unique combination; the aesthetics of a cultural hybridization which can be enthralling in its impact and widely documentary. Does A Dance qualify as a regional drama or does it exude resonances beyond its demographic margins? Soyinka's play can be seen as a universal drama of the human kind with an engrossing theme, the preponderance of evil and corruption in private and public spheres of existence. This paper attempts to show how the treatment of this theme and stylistic techniques employed are equally dynamic and challenging.
\end{abstract}

Keywords: mythic, oral, religion, satire, Yoruba.

The thesis of the paper is as follows:

African literature is characterized by several dominant strands of influence and literary paradoxes both in its oral and written mores and this has evolved from the continent's long history tinctured by the famous traditions of storytelling and performance aesthetics; Africa 's classical traditions going back to the most ancient times in civilization. It was precisely towards the end of the $20^{\text {th }} \mathrm{C}$ that African literature received world wide acclaim and recognition due to a systematized process of study and debate fostered by institutions of education and interpretation. Thus African literature is simultaneously old and timeless besides acclimatizing itself to the global pressures of change and flux. The desire for a distinct cultural and racial identity free from white European domination lay behind much written and oral literary phenomenon. Some of the most compelling literary works of African origin is reminiscent of the most formidable events in Africa's political fortunes, most notably those related to slavery and colonialism. The documentation of South African literature in its initial stages, apart from slave narratives which tried to reclaim memories lost in the process of enslavement; passed through the hands of white settler Europeans who depicted Africa according to White Eurocentric standards of judgment and analysis. Africa became metaphorically the site for desire, the imperial frontier where British superiority was asserted, and Africans viewed as objects of fear and revulsion. Adventure romance and novels like Douglas Blackburn's A Burger's Quixote, 1903 and Sarah Gertrude Millin's God's Stepchildren, 1924 are vibrant reminders of such writings. The dawn of the $20^{\text {th }} \mathrm{C}$ till the establishment of the Apartheid state created a conscious awareness and platform for the negotiation of colonial Englishness pacifying in some measure the demands of a heightened native and local literature. The poetry of Roy Campbell in this regard tried to endorse African themes within a strictly European perspective. What we can convincingly call modern African literature evolved through the institutions of Christianity, the school and later the university. But while this may be true on its own grounds, forms of creative expression in Africa developed outside the confines of colonialism, and the continent's living heritage of oral forms provide an indelible record of an autonomous tradition at work which reached its highest point in the decades of decolonization during the 1950s and 60s when the majority of African countries were becoming independent from foreign rule. Thus literature of this time celebrated the coming into being of a new African nation and with it the assertion of a distinct racial and cultural identity. What was ironic was that by the 1960s, literary narratives in the new liberated environment did not adhere to the utopian ideal that many writers and intellectuals had anticipated; this was because institutions of the colonial past camouflaged themselves and thrived on the very superstructure of decolonization. The continued domination of the African nation by western political and economic interests gave rise to the crisis of decolonization or the crisis of post-colonialism in the 1980s and 1990s.

The cultural dynamics of African literature is defined by multiple traditions and contexts instead of a single consolidated narrative tradition. This is due to innumerable indigenous history, regional and sub regional anthropological factors, ethnic resistance and linguistic as well as sociological traditions that have stood in the way of a unified African literature. The strain of modernist thought and influence on African literature has often eluded critics and led to conflicting responses. Alluding to the key tenets of modernism would entail a break with the sustaining dogmas of an African past heritage, as European modernism asserted its uniqueness by attacking $19^{\text {th }} \mathrm{C}$ traditions of realism. African writers turned to realism in an attempt to give legitimacy to the 
African experience and rediscover the country's cultural potential and geographical energies. According to Modernism, art had a transcendent value; this was quite contrary to the scheme of ideas in traditional African society which had always been holistically linked to art (visual, performance and fine arts) as a provider of powerful signification of collective tribal or cultural affiliations. Art according to the African system of values also exercised a pedagogic function and as such could validate a wider nationalist enterprise of progress and reform.

However Modernism exerted a strange cultural pull and paradox on the African sensibility as the most influential and important African writers were the products of colonial literary education that took its nourishment from European cultural texts and were at odds with the sentiments of the colonized millions. The discourse of modernism opened up new vistas for the African writer who in connection with avant-garde movements of the 1920s and 1930s discovered their divorce with a colonial mindset and a distinctly colonial language. This significant group of African modernist writers of the 1940s and 50s discovered an idiom for rediscovering the African imagination with gusto and vigor and thereby uplifting it from the imitations of European literary forms. These influences are helpful in tracing the matrix of ideas that African sensibility embodied with the changing decades. In the late 1960s and 70s there emerged a generation of African writers who experimented with different stylistic techniques and ideas borrowed from European modernist tradition in order to express the crisis of post-colonialism. In this regard it is also necessary to state that modernism represented a radical break with the idea of realism which was somewhat allied to nationalism and both nationalism and realism were incapable of representing the crisis of post-colonialism. After the colonial regime ended, Africans vying for positions of power, displayed despotic, oppressive, anti nationalist and opportunist tendencies in their political maneuvers. Frantz Fanon in The Wretched of the Earth (1963) accounts for the failure of Nationalism to live up to its ideals and the perpetual dominance of colonial strategies in the newly independent African states. He provides here a powerful but frightening picture of a failed decolonization that would drastically devastate the paradigms in art, society and culture:

"National consciousness, instead of being the all-embracing crystallization of the innermost hopes of the whole people, instead of being the immediate and most obvious result of the mobilization of the people, will be an empty shell, a crude and fragile travesty of what it might have been." (1963, New York)

In some of the prominent works from the period, including writings (novels and plays) by Ama Ata Aidoo, Ayi Kwei Armah, Ahmadou Kourouma, Ngugi wa Thiong and Wole Soyinka, what comes out is a kind of break with the neo-colonial order, a driving penchant to demythologize nationalism itself by fracturing experiences, providing multiple and dispersed responses, validating the subjective over the objective and providing conclusions achieved through the mode of parody and irony. The focus of this paper is on Wole Soyinka' treatment of the Yoruba paradigm in A Dance of the Forests in order to conceive the nascent possibilities of a mythical universe existing alongside the modern dilemma of freedom versus nationalism. Soyinka who became the first black writer from Africa to win the Nobel prize in 1986, has written perceptibly in all genres of literature, be it poetry, drama, autobiography, fiction or the critical essay. According to Soyinka the artist, his geographic and demographic place and the lineage of his artistic traditions are one and inseparable. The first phase of his literary activity emerged in the $60 \mathrm{~s}$ when he returned to his native country Nigeria producing a fruitful series of works like The Lion and the Jewel (1963), A Dance of the Forests (1965), followed by The Swamp Dwellers (1964), The Trials of Brother Jero (1964, a satire on hypocritical, opportunist and shallow politicians) and the radio play Camwood on the Leaves (1973). The political fortunes of Nigeria from the mid 1960s ran into rough waters and a conscientious writer that Soyinka was, he could not remain aloof from the problems that beset the nation. His political sympathies led him to prison where he wrote a prison memoir titled The Man Died (1972) which avowedly criticized the people in administration while stressing on the role of the artist in society. Soyinka's works of the mid and late 60s echo the political turmoil that characterized Nigerian society of that time. Kongi's Harvest (1967) is a critique of authoritarian rule while The Road (1965) is a metaphoric search for death, presented through a character who is inconclusively torn apart in the corrupted urban Nigerian metropolis. Three other plays namely The Interpretors (1965), Madmen and Specialists (1970) and Season of Anomy (1973) should also be interpreted in the light of heightened political dissent and democratic compromises through which the country was passing. Society's degeneration into sectarian violence, an era of crass materialism and a sense of collective disorientation also colours all these works. Soyinka's sustained indulgence and concern with Africa's political and social problems in his works deserves unequal attention for their variety and singular eloquence. In the realm of poetry his long poem "Ogun Abibiman" (1976), with special reference to the lead poem of that collection "Mandela's Earth and Other Poems" (1989) address the Apartheid situation in Africa under the exploitative and racist regime of the Afrikaner nationalist Party. In the decade of the 80s and 90s plays such as Opera Wonyosi (1984), Requiem for a Futurologist (1985), From Zia with Love (1992), and The Beautification of the Area Boy (1995) offer biting indictment of Nigeria political fraudulences under both civil and military rule. A Play of Giants (1984) also satirizes the inordinate lust for power in despotic governments and charts out the gruesome consequences of 
such inhuman tendencies. Keeping in view this background with regard to Soyinka's literary preoccupations, $A$ Dance of the Forests is severe in its warning against a freedom and nationhood that comes at a very high price. In the symbolic action of the play's scheme independence comes at a clinching moment through a maze of past historical errors (as expressed convincingly through the play-within-the-play structure) while prophetically revealing a perilous future with no moral choice in the face of corruption and degenerate moral failings.

A Dance of the Forest is a play which shows how leaders have the capacity to exploit those they lead and how knowledge of self and the state as an institution should be interpreted with regard to the eternal history of oppression. One of the major themes of the play might also be the difficulties involved in making new beginnings, but this apart there are many more themes and subthemes that are interwoven in the dynamism of the play's message. The cast list includes human beings alongside supernatural characters; the action also incorporates rites, masques, flashbacks (much ancient in time) and a series of ritual dances. Moreover the play can be seen as a successful attempt to combine Yoruba traditions of festive drama with the dialogue drama of the European tradition and the major focus on such events as expiation and purification reiterate Soyinks's grim warning about the "recurrent cycle of stupidities" The play begins with a prologue by Aroni, the Lame one, who embarks on a discussion about the Feast of the Human Community and then also refers to important past events during the reign of Mata kharibu. The mention of dead spirits (a dead man and a dead woman), the subject of reincarnation, of the interactions between the human and the superhuman, between the spirit of the ancestors and the humans, between the human and the divine are convincingly elaborated. Spirits and Gods of the Yoruba cult take part in the action, sometimes directly or indirectly, for eg. Ora and Ogun are important cult deities who exert a strong influence on the play as revealed to us in the prologue. The celebration of Independence by creating a totem pole, (the symbol of great reunion) surrounding which the Feast of the Human Community would take place is interesting and creates the prospect of dance, rituals and masques thereby conjuring up the African practice of community performance.

If African religion is to be minutely dissected then various regional variations can be observed. One main distinction is between people who worship nature gods and those who don't. Sometimes belief in a single supreme being is transferred to an allegiance for ancestral spirits. Some of the most advanced and sophisticated African people however repose their faith in hero gods who occupy a middle path between God and the ancestors. Whereas people of Central and Southern Africa do not for the most part believe in Nature gods, leading tribes of West Africa have a large pantheon of gods; for example some of the tribes of Sierra Leone in the far West of Africa regard their ancestors as of utmost importance and have only little faith in other spirits. West Africa also had been traditionally linked to polytheistic practices with worship of various nature gods and their different temples and priests, like that found in the civilizations of Egypt, Greece and India. In one of Soyinka's most celebrated book of critical essays, Myth, Literature and the African World (1976) Soyinka enumerates the position of African mythology in relation to contemporary European worldview. In an essay entitled "The Fourth Stage: Through the Mysteries of Ogun to the Origins of Yoruba Tragedy", he sets out to prove that "the lessons of history and individual or collective struggle are often encoded in mythology." From Yoruba mythology Soyinka chooses the God of Iron and metallurgy - Ogun; he is also the metaphor for artistic and technical excellence and according to popular traditions in Africa, Ogun also typifies spiritual health and is the harbinger of social prosperity. While Ogun symbolizes visionary potency and leadership, other figures in Yoruba mythology like Orisha-nla (arch divinity) or Obatala also occupy an indispensable position. Ogun's position is more contemporarily adequate since he embodies and manifests within him qualities of artistic and technological creativity and vision. In the first part of A Dance Ogun is said to have a palpable hold on Demoke, the artist who will carve the totem pole for the forthcoming event. Demoke is literally a servant to Ogun and Ogun also threatens Murete (a tree imp) for information by forcing down alcohol down Murete's throat. Another wayward cult spirit Eshuoro has been offended because Demoke has injured the sacred Araba tree in which Eshuoro often took shelter. "The Yoruba of Nigeria have many images of an intermediary spirit called Eshu, who is both a messenger and a guardian of man. His image is placed outside houses and villages. But he has an unpredictable character, and is often violent or crafty, and he may express the anger of the gods at human wrongdoing. Eshu is very powerful and only the supreme deity can curb his might..." Perhaps the Eshuoro of A Dance may bear a faint resemblance to the Eshu of the ancient African myth. In the manner of fairy-tale narration we see how the world of human beings, ancestral spirits, Gods and Nature Gods all come together and actively get involved in the affairs of the mundane world. Not only do they get involved they also perpetrate tragic events and vie for supremacy and ascendancy. In one perceptible scene Ogun tells Forest Father (a character) that he will save Demoke from the punishment of cutting down the Araba tree; he would also protect him from the wrath of Oro, whose follower Oremole's death was the result of Demoke pushing Oremole down the totem pole. Gods and spirits often masquerade in the shape of human beings and this is exactly what Ogun does (he masquerades in the figure of Obaneji, father of Demoke) when he promises Forest Father to save Demoke from any untoward danger. 
Spirits according to African systems of belief may "have their abode in any natural object, on every high hill and under every green tree. Hills and outstanding rocks are likely haunts of powerful spiritual forces, and many villages which nestle under these hills take the hill spirit as their principal deity. The town of Abeokuta in Nigeria is built under the rock, as the name implies; the sacred cave of the hill spirit survives and is said to have received a human sacrifice as recently as 1941." Even at Ibadan which is at a distance of some fifty miles to the north of Abeokuta, "the tutelary divinity of the town is a hill goddess in whose honour an annual festival is held." No fires are permitted to burn in any home until the chief worshipper of the hill arrives, and there is general gaiety and rejoicing. Elsewhere "Trees may be sacred. All trees are thought to have souls of their own, and some are regarded as the dwelling places of other powerful spirits which take up temporary abode there." In A Dance of the Forests, Murete is a tree imp who spies on passengers and is a link between humans and spirits, and Demoke incurs the wrath of Oro (possibly a powerful spirit god) for cutting down the Araba tree; which has symbolic as well as sacred value. A popular tree of great importance is the iroko tree (a kind of African oak tree) which is made the site for temple and worship in Africa; often boundary walls like a fence made of leaves demarcate its circumference, and if it has to be cut down propitiation is extremely necessary. Even Baobab trees are believed to be sacred; in its various holes and crevices reside supernatural powers; often this tree becomes the abode of spirits or may be the meeting place of the witches. The forest can thus become a popular abode for dangerous spirits or ghosts. "These may be ancient haunts, such as Zimbabwe, uncut thickets or impenetrable bush. Here live dangerous ghosts of men who have been lost, or drowned or burnt alive and have not received proper burial. Non-human spirits are there too, grotesque dryads and demons that prey on heedless men (as in Amos Tutuola's book My life in the Bush of Ghosts)." In A Dance of the Forests, the forest is a site for vital actions and also echoes the mythic dimension of the play as a whole. The whole of part one is devoted to a discussion between the four living characters, Obaneji, Adenebi, Rola and Demoke taking the lead role. There are some less important characters like the Old Man, Agboreko and the Dirge-man. The action reveals the living characters comment on the Dead pair as unworthy ancestors; there is also some talk about a tragedy that took place due to human greed and lust. Ancestors in African society retained the clan's claim for pride, wisdom and honour and in certain cases were restless and aggressive like animals, few were also unpredictable and dangerous, represented by animals of the bush. In South Africa "the ancestor spirits are the most intimate gods of the Bantu: they are part of the family or tribe, and are considered and consulted on all important occasions." In Rhodesia, "the family divinities are the ghosts of one's grandfathers, grandmothers, father and mother, uncle and aunts, brothers and sisters." The Ibo tribes are also nourished by the belief that their lives owe a lot to their ancestors, and are profoundly influenced by them; sacrifices at regular intervals have to be offered whenever a diviner indicates. In one predominant African community most people never drink or eat without throwing a morsel in the names of their ancestors. This apart the gradations of ancestors are also very important keeping in view their acts when alive. A particular group of ancestors may be highly revered for their feats and fame while another group of forefathers could be normal spirits from the distant past who guided and supported future generations in their dealings and day to day affairs. Thus there was no doubt that ancestors had a great role to play in African scheme of thought and familial allegiances. Among the Ashanti popular spirits of warriors took the lead role in war and their help was always invoked. Towards the end of the first part in A Dance of the Forests, an elaborate ritual is enacted which is undertaken by the Dirge-man, Agboreko and dancers; this ritual is also supposed to invoke ancestral spirits. Agboreko makes his prophecy with the help of the divination board, bowls and kernels. Both the dirge-man and Agboreko take turns to utter statements, referring to stories or legends from Yoruba myth:

Agboreko: The eye that looks downwards will certainly see the nose. The hand that dips to the bottom of the pot will eat the biggest snail. The sky grows no grass but if the earth called her barren, it will drink no more milk. The foot of the snake is not split in two like a man's or in hundreds like the centipede's, but if Agere could dance patiently like the snake, he will uncoil the chain that leads into the dead...

[Enter the beaters, shouting. The flogger immediately breaks through them and sets out to clear a space with his long whip, which he freely exercises. The dancer follows almost at once, followed by his acolyte (a very intense young girl). She sprinkles the cleared space after the flogger. The dirge-man begins to recite within a few minutes of their entry. An assistant hands Agboreko the divination board, the bowl and kernels.]

In Africa various kinds of oracles are used in order to unravel the future or discover the will of Gods and the ancestors. "There was no writing in tropical Africa in the olden days, but there were complicated systems of divination which used notation that was a kind of writing or means of recording and communicating. Such systems are known from Senegal to Malagasy, but the most famous is the Ifa divination of the Yoruba of Nigeria, which has been borrowed by neighboring countries. Ifa is a spirit often identified with a god called Orun-mi-la," which means the ways of salvation are best known by heaven. In various other regions such as in Transvaal, "the Venda people use four pieces of flat ivory for divination, and other peoples use dice of wood carved with designs of beasts like crocodiles. The four dice represent members of the family: old man, old woman, and young woman. They are thrown into sixteen possible combinations and diviners have 
interpretations for each combination." Again divining bowls filled with water with a few other important objects were used for discovering secrets, predicting the future or knowing the hidden haunts of witches in regions of tropical Africa. In parts of "southern Africa only the Venda and the Karanga of Rhodesia use such divining bowls, with patterns and pictures round the side of the bowl, and a cowrie shell in the middle which is called the umbilicus and represents the spirits of the mother. However in the ruined buildings of Zimbabwe in Rhodesia similar soapstone bowls have been found, decorated with figures such as bulls."

One of the most sustained examples of ritualized drama emerges in the second part of the play which foreshadows a time much earlier in history about eight centuries ago in the court of Mata Kharibu. It is a playwithin-the-play which is enacted through a flashback technique. All the anomalies of kingship, the vagaries of human nature, an inordinate lust for power and above all ruthless personal gain are projected through an event voicing Soyinka's indictment of the concept of moral failings. Through the welcome of the Dead ceremony Eshuoro believes the regeneration of man will take place, as man had been earlier responsible for destroying the forest and its spiritual entity and ecology. Clamoring for justice Eshuoro and others wait in anticipation as the scene shifts to the court of Mata Kharibu. An ongoing conflict of values is presented, an impending war threatens to disrupt justice and the king's court is in a state of turmoil. The Historian (Adenebi), the Physician (the Old Man), the Soothsayer (Agboreko), the court Poet (Demoke), and Madam Tortoise (Rola) all assume different strategies to put their point across and intrigue follows. From a crisis situation in the play in which good is contested against evil, the scene suddenly shifts to that of a mime play where amidst a damp and drizzly atmosphere interrogation of hazy characters from the underworld or the world of the dead begins. A volley of questions follow, revelations commence with the voices of reincarnated figures, an interpreter figure assists in further developments until an elaborate group of spirits speak out their prophecies. There is the Spirit of the Palm who speaks of punishment for those who have sinned, the Spirit of Darkness joins in and speaks of the doomed. The Spirit of Precious Stones says how it promises men eternal wealth but in the very next instance, deludes or incites lust in order to befool and deceive. The Spirit of the Pachyderms complains of the theft of ivory and the Spirit of the Rivers repents for the unbound lust of human beings in exploiting the environment. The Spirit of the Sun complains of an untimely eclipse while the Spirit of Volcanoes says that he has lost the capacity to emit larva. There is an Ant leader who complains that his race is perpetually trampled under foot by humans. Amidst these shady figures a Half-Child(a child yet to be born) heightens the tempo of action by playing and dodging the spirits, then the Triplets appear, much like the witches' prophecy in Shakespeare's Macbeth. A ritualized dance takes place between the Interpreter and the Triplets who let out a series of cynically strange sinister prophecies. The first of the triplets speak of the end justifying the means, the second speaks of excusing sin if it can pronounce a better future and the third triplet announces with climactic finality that it is posterity nourished by violence and blood. The appearance of the triplets are none the less frightening, they represent vagaries and oddities of nature and the mood of feverish excitement is categorically heightened by the dance of the Half-Child. "Twins, and even more triplets, are regarded with mixed feelings of fear and joy, as abnormal, even animal, births. In eastern Nigeria they used to be exposed in pots in the forest. But in western Nigeria and Dahomey they are prized, as the gods themselves, it is believed, were born in pairs. Images of twins were used for rituals, and in front of them offerings were placed in twin pots. If a twin dies the survivor, or the mother, wears a wooden image of the dead one tucked in the waist cloth. In Buganda twins were said to come from the great God Mukasa, and doctors made ceremony to ensure health and prosperity. The Thonga of Mozambique called twins 'children of the sky', but thought their birth a great misfortune which needed rituals of purification."

In the next scene of $A$ Dance of the Forests, there is no spoken word but it is highly charged and animated, revealing the hot pursuit of Eshuoro, the Third Triplet, Ogun and demoke to reclaim the Half-Child. This Dumb show takes place amidst a terrific confusion where identity is shrouded behind masks and melodramatic change of scenes take place, dance and danger intercede and collaborate to create the desired impact for the Forest Father's speech which is a warning for mortals to take lessons from historical failures in order to avoid similar catastrophes of the past. Towards the close of the play Demoke's totem pole and ritualized gestures of purification, expiation, libation, sacrifice and suffering present itself in quick succession of images. Dancing persists in all its intensity, and one is made aware of the sacrifices that have been made at a very high price. Yet wisdom is a far-away dream and the play ends with an inconclusive hope of salvation that is yet to dawn on humans.

A Dance of the Forests thus emerges as a rare instance of drama that fuses together mythology, mime, dumb show, the spoken word and other devices like a Play-within-the-Play to structure a unique piece of satire on human propensity for evil. In the foreword of one of his plays, Opera Wonyosi, Soyinka envisages his task as "the turning up of the maggotinfested underside of the compost heap as a prerequisite of the land's transformation" and the playwright proposes how the reformist and revolutionary implications of satire is best fulfilled by arousing a certain degree of nausea towards a particular situation and then suggests an alternative that can bring change and reform. Soyinka achieves the effect of satire through the depiction of a mythological paradigm which convincingly moves back and forth between the past and present linking up events, motives and ideas into a composite whole. The message of the play is to be minutely 
dissected from the ending which in philosophic terms helps to pronounce the final judgment albeit in an innocuous way.

Within the domains of "African social history, works of art have been the most powerful signifiers of collective cultural or tribal affiliation, and different African groups have come to be associated with their most prominent forms of visual art. Thus it is hard to think of the Asante without the images of their delicate gold figures or the Fang and Senufo without their evocative mask figures. Representation of artistic forms such as masks in writing are often used to explore African mentalities, cosmologies and essential identities or to frame debates on the value of culture. For writers such as Wole Soyinka or filmmakers like Ousmane Sembene visual art has been the basis of a rethinking of the black aesthetic and the politics of representation." Thus the abundant use of masks in the second part of $A$ Dance is important in signifying and retrieving distinct tribal and cultural dimensions of the African ethos. The power of the god Ogun that occurs virtually throughout the play, is linked to an Yoruba myth which goes by the story of the Iron god Ogun who came down from heaven to visit the world through a spider's web and often hunted in the marshes; this was at a time when the earth was watery and ill formed. "Later the earth was formed by Great God, who set about arranging everything in order. But he came to thick forest that his tools could not cut, since they were only bronze. Ogun alone, whose axe was iron, was able to clear a way, and he only did this after the other gods had promised to reward him. So when they built their sacred city of Ile-Ife, they gave him a crown. But the iron god did not want to rule his fellows, since he still enjoyed hunting and battle, and for a longtime he lived alone on a hilltop, from whence he could watch over the land and spy out his prey. When finally he came to the gods they did not want to harbor him, for his clothes were stained with blood. So he made clothes from the bark of a palm tree and went to live elsewhere."

Soyinka's work thus expresses a profound knowledge of someone who is equally well-versed in the European intellectual traditions while having a close affinity to Yoruba frames of reference. The Swedish Academy describes him as "a writer who in a wide cultural perspective and with poetic overtones fashions the drama of existence." Again and again Soyinka's works returns to particular themes and areas of interest which center on the responsibility of an individual towards himself and to his community, his position in society, the place of Christianity and the Western theatrical tradition and above all the vigorous influence of the past in today's contemporary world. His mythical paradigms reiterate this challenge and enigma and in plays such as The Strong Breed (published in Three Plays; performed, 1966) the elements of ritual and sacrifice are more convincingly integrated into the narrative. In The Road the Yoruba pattern of life and death and the continuity of one into the other, besides song, ritual and the veiled story line help to express the plays message as a satire on corrupt policemen, drugs, criminals and unscrupulous politicians, though there is a bit of obscurity and complexity with which Soyinka delivers his moral vision. The year 1966 was also the time when Soyinka was celebrating the First Rite of the Harmattan Solstice, with a few poems written in Yoruba in the manner of Yoruba praise poem (Oriki). During the later part of that year his poetry turned avowedly political in its impact; one obviously understands this by a reading of his verse in Idanre and Other poems, which while employing the Yoruba mythical figures of Ogun, Atunda, Sango, Oya and the Idanre Hills as an oracle, also embody scenes of violence and reports of massacres as a metaphor of mayhem and carnage. But for all his political engagements and social commitments Soyinka's work as a writer is largely that of a mythopoet for whom Yoruba myths provide a platform for depicting survival strategies and effect the metamorphosis of change, of experience even inexperience and the paradoxes of life itself in the act of living. According to most critics Soyinka's works have made a great contribution to the English-language theatre in an unparalleled way, and his creative endeavor has been highly acclaimed, with occasional speculative comments about the Nigerian response of his texts in performance. Text based criticism has failed to register the enthusiasm and delight of Soyinka's audiences among whom his plays continue to grow in popularity and appeal.

\section{Works cited}

[1] 1 S. Gikandi. (Ed.) Encyclopedia of African Literature. (London, U.S.A., Canada: Routledge, 2003) P 371.

[2] 1 B. Lindfors, and R. Sander. (Ed.) Twentieth Century Caribbean and Black African Writers. Second Series. Dictionary of Literary Biography 125. (UK, U.S.A.: Gale Research International Ltd, 1993) P 306.

[3] $1 \mathrm{~S}$. Gikandi. Encyclopedia of African Literature. P 521.

[4] 1 E. G. Parrinder. (Ed.) African Mythology.p 90.

[5] E. G. Parrinder. (Ed.) African Traditional Relegion. 3rd Edition. (London: Sheldon, 1975) P 52

[6] 1 Ibid.p 52

[7] 1 Ibid.p 52

[8] 1 Ibid p 53

[9] 1 Ibid. p 57

[10] 1 W. Soyinka. Collected Plays 1. (London, New York: Oxford University Press, 1973) P 36.

[11] 1 G. Parrinder. (Ed.) African Mythology. p 88.

[12] 1 G. Parrinder. (Ed.) African Mythology. p 89.

[13] 1 G. Parrinder. (Ed.) African Mythology. p 51.

[14] 1 W. Soyinka. In Person: Achebe, Awoonor and Soyinka at the University of Washington, Karen L. Morell. (Ed.) Drama and the Revolutionary Ideal (Seattle, Institute of Comparitive and Foreign Area studies/University of Washington, 1975 ) P 127.

[15] 1 S. Gikandi. (Ed.) Encyclopedia of African Literature. P 31.

[16] 1 G. Parrinder. (Ed.) African Mythology. (London: paul Hamlyn, 1967, 1969) P 79.

[17] 1 B. Lindfors, and R. Sander. (Ed.) Twentieth Century Caribbean and Black African Writers. p 301. 